\title{
Proceeding
}

Supplementary Issue: Summer Conferences of Sports Science. Costa Blanca Sports Science Events, 25-26 September 2020. Alicante, Spain.

\section{The educational value of rules in basketball}

\author{
GAETANO ALTAVILLA ${ }^{1} \triangle$, TIZIANA D'ISANTO², FRANCESCA D'ELIA² \\ ${ }^{1}$ Faculty of Kinesiology, University of Split, Split, Croatia \\ 2University of Salerno, Italy
}

\begin{abstract}
The game rules of team sports and the technique and tactical methods applicable to them are indispensable for practicing competitive sports. The correct competition arose from the automatic mechanism of the sanction following the infringement of a game rule which is also aided by the individual members of the group who demand the application of the rule to continue playing. The competition can also be self-regulated by the two groups who compete without even the decisive action of the referee as happens in training activities. The aim of the study is to identify the significant elements of the game rules and the related technique and tactical behaviours in individual team sports and to identify an inventory of significant behaviours. The method is documentary archival research for the analysis of the rules of individual team sports, a subsequent comparative method between grids of indicators, descriptors and weights that classify rule, technique and tactics. The expected results will focus on the appropriate presence of the significant elements and the commonality or discrepancy between team sports. The data is useful for measuring the quantity of significant behaviours in order to qualitatively elaborate the value of each of them with respect to the other current behaviours of quantitative performance and establish the connections. Subsequently, requests for selfperception can be administered to practitioners (athletes and students) on the specific connections between the need for the rule and its application in order to play sports at the highest levels with gratification and satisfaction.

Keywords: Basketball; Rules of the game; Educational aspects; Principles of technique; Individual and group tactics.

Cite this article as:

Altavilla, G., D'Isanto, T., \& D'Elia, F. (2020). The educational value of rules in basketball. Journal of Human Sport and Exercise, 15(4proc), S1195-S1203. doi:https://doi.org/10.14198/ihse.2020.15.Proc4.21

Corresponding author. Faculty of Kinesiology, University of Split, Split, Croatia. http://orcid.org/0000-0001-8436-7819

E-mail: gaetano.altavilla@unimol.it

Abstract submitted to: Spring Conferences of Sports Science. Costa Blanca Sports Science Events, 19-20 June 2020. Alicante, Spain.

JOURNAL OF HUMAN SPORT \& EXERCISE ISSN 1988-5202

(c) Faculty of Education. University of Alicante

doi:10.14198/jhse.2020.15.Proc4.21
\end{abstract}




\section{INTRODUCTION}

Basketball is a cooperative sport that is played by two teams of five players each. It is a sport of the situation, for sports situation means all those sports in which it is not possible to predetermine the actions that will occur in the development of the game (Altavilla \& Raiola, 2014). It is a team sports that present multiple and different dynamics during the game as a result of variability in offensive and defensive plays (Bourbousson et al, 2010), there is physical contact between two teams but in respect of the rules. In basketball game the shot is the main action of the attacker (Raiola et al, 2016), in fact, every player must be able to score baskets, and therefore points, and at the same time defend: it attacks in five and defends itself in five. However, there is a differentiation of roles between the players: the playmaker is the one who builds the game (the team director); big forward generally has the task of scoring baskets from a medium distance, but also close to the basket. The pivot (Centre) is the tallest player on the team and his task is to play close to or from behind the basket in order to shoot or overturn the ball on the weak side of the defence; as well as recovering rebounds, both in defence and in attack. The small forward, in addition to having a good shot, has a considerable elevation and therefore can recover several rebounds; finally, the guard helps the playmaker to lead the ball in attack, has an excellent shot and good technique-athletic skills in $1 \mathrm{c} 1$ and for pressing opponents. In all team sports, it is good to know the basics and use them according to the different game situations (Altavilla et al, 2017). In particular, basketball present multiple and different dynamics during the game as a result of variability in offensive and defensive performances (Altavilla \& Raiola, 2019).

Basketball is not just a game of action and reaction is also a sport of anticipation (Raiola, 2015), the ability to correctly predict the development of an action of the opponents and to program their own, in order to choose the technique and tactical actions that will produce optimal results (Izzo et al, 2015). This motor plasticity obviously requires a plasticity of thought that must always be maintained even when the technique is mastered (Ceruso et al, 2019), which must never become oppressive and condition the player's intelligence. In fact, in addition to technique, tactical and physical skills, the mental aspect is becoming more and more predominant in basketball (Jingsheng et al, 1999). In team sports much of practice is coach-determined (Helsen et al, 1998), he does not prepare only a periodized training's plain (Raiola \& D'Isanto, 2016; Bompa \& Haff, 2009), but he must also send continuous feedback to the group, aware of the their potential and limitations. The coach's goal is first of all to train talented, autonomous and responsible players (Burgess \& Naughton, 2010), able to face and resolve game situations in the interest of the team, using the fundamentals of the game (Sgrò et al., 2019; Sgrò et al.,2017). The role of the coach cannot only be linked to technique skills, but interpersonal skills are also essential. He works on the importance that the improvement of the qualitative and quantitative aspects day after day (Kamandulis et al, 2013), is an excellent alternative goal to sporting success at any cost (Gaetano et al, 2015), he knowing that the athletes are subjected to different strengths and consequently to different stresses (Falcone et al, 2019).

It is useful to highlight the continuous individual and team improvements to keep the motivation and pleasure of competition high, to work on team cohesion by pointing out to the players that it is necessary to overcome some natural misunderstandings between different characters, aware that these aspects will do the difference in the most difficult moments of the match (Esposito et al, 2020ab). Just as it is important to strongly express one's ethical convictions by giving space to one's role as educator, observing (D'Elia et al., 2020, Raiola et al., 2020), teaching and promoting respect for adversaries and diversity (Valentini et al, 2018), fundamental values for a civilized life and that sport helps to overcome linguistic, cultural and social barriers (Federici et al, 2014; Haga et al., 2018). A further aspect that must emerge in carrying out the task of coach is to build the concept of "team", highlighting the importance and usefulness of all the players, developing the winning idea that working together for the same goal is possible to obtain a good performance (Ferrara et al., 2019), 
that is influenced by a series of factors (D'Isanto et al, 2019): technique, tactical, physical and mental (Tortella et al., 2019). The aim of this sport is to score one point more than the opposing team and to achieve this it is essential to implement all the strategies necessary to make baskets or not to let the opponents do them. Strategies are nothing more than the ways in which a person makes decisions, acts and motivates himself. For a player, choosing the best strategy to implement (Gréhaigne et al, 1999) presupposes the acquisition of good technique (game fundamentals and are the tools we give to players to solve game situations effectively) and good tactics (the ability to choose in using the most appropriate fundamental and in the right space and with the right time).

\section{Aim of study}

The aim of the study is to identify the significant elements of the game rules and the related technique and tactical behaviours in individual team sports and to identify an inventory of significant behaviours.

\section{MATERIAL AND METHODS}

The method involves in the first phase the documentation archive research for the analysis of the rules of individual team sports, then a comparative method between grids of indicators, descriptors and values that classify the rule, technique and tactics. Once the basketball game rules have been identified, a connection was then established for each between the rule itself (indicator) and the technique (1st descriptor) and tactical (2nd descriptor) aspects and then identifying the weight, i.e. the connection (close, medium, low) between indicator and linked descriptor. Subsequently, the relationship-connection of each of the elements identified with the performance data was descriptively identified, evaluating the degrees of physical effort (maximumaverage-minimum), strength (maximum-average-minimum), and speed (maximum-average -minimum).

\section{RESULTS}

Table 1. Indicator, descriptors, connection between indicator and descriptor, connection with the performance data.

\begin{tabular}{|l|l|l|l|l|l|l|}
\hline Indicator & 1st Descriptor & 2nd Descriptor & $\begin{array}{l}\text { Connection } \\
\text { Indicator- } \\
\text { Descriptor }\end{array}$ & \multicolumn{2}{|l|}{$\begin{array}{l}\text { Connection with the performance } \\
\text { data }\end{array}$} \\
\hline Rule & $\begin{array}{l}\text { Technique } \\
\text { proposal }\end{array}$ & Tactical proposal & Weight & $\begin{array}{l}\text { Degree of } \\
\text { physical } \\
\text { commitment }\end{array}$ & $\begin{array}{l}\text { Degree } \\
\text { of } \\
\text { strength }\end{array}$ & $\begin{array}{l}\text { Degree } \\
\text { of speed }\end{array}$ \\
\hline $\begin{array}{l}\text { The ball is } \\
\text { played with the } \\
\text { hands and can } \\
\text { be passed, } \\
\text { thrown, rolled or } \\
\text { dribbled in any } \\
\text { direction. It } \\
\text { cannot be } \\
\text { deliberately } \\
\text { carried or kicked. }\end{array}$ & $\begin{array}{l}\text { Propose within the } \\
\text { session a moment } \\
\text { dedicated to } \\
\text { awareness-raising } \\
\text { exercises (ball- } \\
\text { handling). It also } \\
\text { allows you to } \\
\text { improve grip and } \\
\text { reception. }\end{array}$ & $\begin{array}{l}\text { Of particular } \\
\text { interest to recreate } \\
\text { exercises based on } \\
\text { "give and go", "give } \\
\text { and follow" and } \\
\text { "give and change" } \\
\text { in order to become } \\
\text { familiar with the } \\
\text { tactical principles of } \\
\text { the game. }\end{array}$ & Close & Maximum & Medium & Maximum \\
\hline $\begin{array}{l}\text { Whoever } \\
\text { receives the ball } \\
\text { can move with } \\
\text { the ball but, } \\
\text { within the third }\end{array}$ & $\begin{array}{l}\text { It is necessary to } \\
\text { work on the } \\
\text { fundamental } \\
\text { technique of } \\
\text { dribbling (it allows }\end{array}$ & $\begin{array}{l}\text { The action of the } \\
\text { passage must be } \\
\text { coordinated and } \\
\text { regulated with } \\
\text { respect to the }\end{array}$ & Close & Maximum & Medium & Maximum \\
\hline
\end{tabular}




\begin{tabular}{|c|c|c|c|c|c|c|}
\hline $\begin{array}{l}\text { step, he must get } \\
\text { rid of it. }\end{array}$ & $\begin{array}{l}\text { you to move on the } \\
\text { field while } \\
\text { maintaining } \\
\text { possession of the } \\
\text { ball) and on the } \\
\text { various types of } \\
\text { passing (two- } \\
\text { handed from the } \\
\text { chest, two-handed } \\
\text { crushed and } \\
\text { baseball). }\end{array}$ & $\begin{array}{l}\text { needs and position } \\
\text { of the one who } \\
\text { must receive. You } \\
\text { must be very } \\
\text { careful in receiving } \\
\text { the ball in the } \\
\text { correct way. }\end{array}$ & & & & \\
\hline $\begin{array}{l}\text { The attacking } \\
\text { team has } 24 \\
\text { seconds to set } \\
\text { up and conclude } \\
\text { the attacking } \\
\text { action under } \\
\text { penalty of loss of } \\
\text { possession. }\end{array}$ & $\begin{array}{l}\text { Pay attention to the } \\
\text { individual } \\
\text { fundamentals } \\
\text { without the ball to } \\
\text { set up a game } \\
\text { action, (changes of } \\
\text { direction, direction } \\
\text { and stop) in } \\
\text { addition to the } \\
\text { fundamental of the } \\
\text { shot for a basket. }\end{array}$ & $\begin{array}{l}\text { Define a rational, } \\
\text { elastic and } \\
\text { balanced game } \\
\text { system in the two } \\
\text { game phases. }\end{array}$ & Close & Medium & Minimal & Minimal \\
\hline $\begin{array}{l}\text { Any contact with } \\
\text { the opponent, } \\
\text { unless it is } \\
\text { fortuitous, is } \\
\text { prohibited. }\end{array}$ & $\begin{array}{l}\text { Interception, } \\
\text { fundamental } \\
\text { defensive position } \\
\text { on player with ball. }\end{array}$ & $\begin{array}{l}\text { Work on both zone } \\
\text { and man defence. } \\
\text { Try the typical } \\
\text { defensive actions of } \\
\text { doubling down, } \\
\text { bouncing, and } \\
\text { breaking out. }\end{array}$ & Close & Maximum & Medium & Maximum \\
\hline $\begin{array}{l}\text { There is a free } \\
\text { throw, which } \\
\text { takes place at } \\
\text { the ends of the } \\
\text { areas located in } \\
\text { front of the } \\
\text { basket, the } \\
\text { opponents } \\
\text { cannot hinder its } \\
\text { execution. }\end{array}$ & $\begin{array}{l}\text { Free throw training } \\
\text { by changing basket } \\
\text { and maintaining a } \\
\text { minimum } \\
\text { achievement } \\
\text { percentage. }\end{array}$ & $\begin{array}{l}\text { In technique } \\
\text { exercises, it is very } \\
\text { important to } \\
\text { establish the } \\
\text { maximum distance } \\
\text { from which to shoot. } \\
\text { A good, albeit } \\
\text { empirical, method } \\
\text { to establish this } \\
\text { distance is to have } \\
\text { the young player } \\
\text { shoot from under } \\
\text { the basket and then } \\
\text { move away from } \\
\text { him one step at a } \\
\text { time. }\end{array}$ & Close & Medium & Medium & Medium \\
\hline $\begin{array}{l}\text { The strict rules of } \\
\text { time. A player } \\
\text { cannot hold the } \\
\text { ball in his hand } \\
\text { without dribbling } \\
\text { for more than } 5 \\
\text { seconds, he } \\
\text { cannot remain in }\end{array}$ & $\begin{array}{l}\text { Collaborations in } \\
\text { attack: the blocks. }\end{array}$ & $\begin{array}{l}\text { The counter-attack } \\
\text { technique assumes } \\
\text { particular } \\
\text { importance in the } \\
\text { attacking game. } \\
\text { Counter-attack } \\
\text { simulations are } \\
\text { needed from }\end{array}$ & Close & Maximum & Medium & Maximum \\
\hline
\end{tabular}




\begin{tabular}{|c|c|c|c|c|c|c|}
\hline $\begin{array}{l}\text { the opponent's } \\
\text { area for more } \\
\text { than } 3 \text { seconds; } \\
\text { a team cannot } \\
\text { own the ball } \\
\text { without crossing } \\
\text { the halfway mark } \\
\text { for more than } 8 \\
\text { seconds. }\end{array}$ & & $\begin{array}{l}\text { various situations: } \\
\text { from a basket } \\
\text { immediately, a } \\
\text { defensive rebound } \\
\text { following a wrong } \\
\text { shot or from a } \\
\text { lineout. }\end{array}$ & & & & \\
\hline $\begin{array}{l}\text { The passing rule } \\
\text { is an infraction } \\
\text { which is applied } \\
\text { if a player jumps } \\
\text { with the ball in } \\
\text { hand or if he } \\
\text { takes more than } \\
\text { two steps without } \\
\text { dribbling. }\end{array}$ & $\begin{array}{l}\text { Move with the ball } \\
\text { developing } \\
\text { sensitivity and } \\
\text { automaticity. }\end{array}$ & $\begin{array}{l}\text { To manage the } \\
\text { game and conduct } \\
\text { it in the most } \\
\text { advantageous way } \\
\text { for your team, you } \\
\text { need to work on } \\
\text { both one-half and } \\
\text { two-half stops. }\end{array}$ & Close & Maximum & Medium & Maximum \\
\hline $\begin{array}{l}\text { The double } \\
\text { dribble rule is an } \\
\text { infraction that is } \\
\text { applied if a } \\
\text { player dribbles, } \\
\text { stops dribbling } \\
\text { and then starts } \\
\text { dribbling again. }\end{array}$ & $\begin{array}{l}\text { Move with the ball } \\
\text { developing } \\
\text { sensitivity and } \\
\text { automaticity }\end{array}$ & $\begin{array}{l}\text { It is necessary to } \\
\text { practice } \\
\text { concentration, } \\
\text { speed of execution, } \\
\text { imagination and the } \\
\text { effectiveness of } \\
\text { movements with } \\
\text { and without the ball. }\end{array}$ & Close & Maximum & Medium & Maximum \\
\hline $\begin{array}{l}\text { Each player can } \\
\text { commit up to five } \\
\text { fouls. At the fifth } \\
\text { foul committed is } \\
\text { expelled. }\end{array}$ & $\begin{array}{l}\text { Quick and } \\
\text { explosive } \\
\text { exercises with the } \\
\text { Loop Bands to } \\
\text { refine your stance } \\
\text { and anticipation. }\end{array}$ & $\begin{array}{l}\text { Slow down the } \\
\text { "timing" of the } \\
\text { offensive action } \\
\text { (coordinate your } \\
\text { action with that of } \\
\text { your teammates); } \\
\text { eliminating and the } \\
\text { lines and angles of } \\
\text { passage preferred } \\
\text { by the opponents } \\
\text { and breaking the } \\
\text { "timing" of the } \\
\text { opponent's attack. }\end{array}$ & Close & Maximum & Maximum & Maximum \\
\hline $\begin{array}{l}\text { If a team passes } \\
\text { the ball on } \\
\text { offense and then } \\
\text { back on the } \\
\text { defence the foul } \\
\text { of the offense is } \\
\text { triggered, it will } \\
\text { be resumed with } \\
\text { the opposing } \\
\text { team's throw-in } \\
\text { from the midfield. }\end{array}$ & $\begin{array}{l}\text { Training in 1vs1 } \\
\text { trying to beat the } \\
\text { opponent thanks to } \\
\text { speed and } \\
\text { cunning, using a } \\
\text { series of feints or } \\
\text { anticipating the } \\
\text { intervention. }\end{array}$ & $\begin{array}{l}\text { Useful is the cross } \\
\text { dribble (crossover). } \\
\text { This dribble is quite } \\
\text { effective, as it } \\
\text { allows you to } \\
\text { maintain your } \\
\text { inertia after a } \\
\text { simple weight shift. }\end{array}$ & Close & Maximum & Medium & Maximum \\
\hline
\end{tabular}




\section{DISCUSSION}

When a player receives the ball from a team-mate he places himself in a triple threat position, that is, he can follow a pass, dribble or shot. A possible technique proposal is to recreate exercises based on "give and go", "give and follow" and "give and change" in order to become familiar with the technique and tactical principles of the game. Therefore, we refer to the collective attacking fundamentals that allow to improve the grip and reception of the ball. The first foot that was on the ground when the ball was picked up is called the "cornerstone foot", because the player can rotate on himself while holding it still and moving the other. If he moves his pivot foot "he commits an infraction of steps": the referee blows his whistle and the ball passes to the opponents.

The technique proposal identified foresees to work on the fundamental technique of dribbling and on the various types of passing. The correct execution of the dribble requires considerable sensitivity and automaticity, which are obtained with constant and continuous exercises. The dribble is used to move the ball from the defence to the attacking zone, to position itself in a place from which it is easier to shoot for a basket or to find more space to make a pass when you have managed to get away from an opponent. In order to get rid of the ball and not commit the infringement, it is important to know how to pass the ball correctly. The transition must always be performed with speed and precision; this second component must not be compromised by the first. Therefore, the action of the passage must be coordinated and regulated with respect to the needs and position of the one who must receive.

The infraction of steps rule is an infraction that applies if a player jumps with the ball in hand or if he takes more than two steps without dribbling. It is a rule for which it is technically important for the player to technically acquire sensitivity and automaticity in moving with the ball for which tactically it is proposed to work on both one-half and two-half stops, to manage the game in the most advantageous way for the own team. The attacking team has 24 seconds to set up and conclude the attacking action under penalty of loss of possession. For this rule it is technically proposed to set up a game action paying attention to the individual fundamentals without the ball that allow you to manage the game and conduct it in the most advantageous way for the team (change of direction, sense, stop), in addition to the fundamental of the shot for a basket. The shot allows you to conclude the attack action.

The basket being much higher than the starting position of the shot, in order for the ball to enter the basket from the other down, it will have to travel an ascending parabola in the first phase and descending in the final phase. The shot for a basket can be carried out in different ways (one-handed shot over the head, third time, tap-in, free throw). Closely linked to the fundamental of the shot we also find the rule: free throw is foreseen, which is carried out at the ends of the areas located in front of the basket, the opponents cannot hinder its execution. For this rule, exercises are tactically proposed in which it is very important to determine the maximum distance from which to shoot. A good method, albeit empirical, to establish this distance, is to pull the young man from under the basket and then move away from the same one step at a time. Any contact with the opponent unless it is fortuitous is prohibited, for this rule the technique proposal concerns the defensive tactics and therefore the fundamental defensive position on the player with the ball: feet positioned slightly wider than the width of the shoulders; weight on the forefoot; active hands and arms; palms of hands facing the ball; head straight and eyes looking.

Tactically it is important to work on both defence possibilities, both in the zone and in the man: outbreaks, doubling of marking, pressing. If a team passes the ball in attack and then back in defence the foul of the offense is triggered, it will be resumed with a throw-in from the opposing team's midfield. As soon as they win 
the ball, the players must be able to put up an attacking action with great speed. They must therefore know how to move on the pitch and be ready to receive, pass and shoot the ball without hesitation. If the opposing team adopts a defence strategy (man to man) they will use many blocks and markings without the ball, individual tactics, give and go, one on one. For the identified rule, in fact, the fundamental 1c1 is technically proposed to be adopted when a player has to deal directly with a single opponent, especially if he cannot pass the ball to a teammate; in similar cases they try to beat the opponent thanks to speed and cunning, resorting to a series of feints or anticipating his intervention. From a tactical point of view, cross dribbling can be useful.

\section{CONCLUSION}

The match analysis showed that the basketball players, during a match, perform sprint, with and without changes of direction (Schot et al, 1995), at different velocities (Ben Abdelkrim et al., 2007), over short distances $(10<20 \mathrm{~m}$ ) and of short-lasting (Crisafulli et al., 2002) up to 20 seconds (Narazaki et al., 2009). It is necessary to make decisions in a very short time and to act in a coordinated way with your teammates: you must therefore also have great mental alertness and quick reflexes. Heart and lungs are alternately engaged in aerobic and anaerobic moments. $80 \%$ of the rules identified the connection between the indicator and the performance data relating to speed is maximum. In fact, a basketball player is more interested in vertical jump and acceleration than in maximum speed. Therefore, basketball is one of the most demanding sports, since it involves an important effort both in moving around the field and in situations that involve contact with opponents. Furthermore, ball management requires specific dexterity in dribbling and a coordinated execution of fundamental movements, such as shooting and passing. Once you have a sufficient knowledge of the rules you can apply the fundamentals and game schemes. It is appropriate to evaluate the commitment, compliance with the rules, self-control, tactical sense, decision making, technique qualities, motor imagination and the effectiveness of the player's movements without the ball. These aspects intersect and add important value to the technique execution of the fundamental, the physical qualities, the skills and competences acquired, and to build a cohesive and winning team.

\section{REFERENCES}

Altavilla, G., \& Raiola, G. (2019). A brief review on physiological commitment in basketball: An interpretative key. Journal of Human Sport and Exercise, 14(1proc), S59-S65.. https://doi.org/10.14198/ihse.2019.14.Proc1.07

Altavilla, G., Di Tore, P.A., D'Isanto, T., Raiola, G. (2017). Some teaching method elements of the basketball dribble. Journal of Sports Science, 5:207-210. https://doi.org/10.17265/23327839/2017.04.003

Altavilla, G., \& Raiola, G. (2014). Global vision to understand the game situations in modern basketball. Journal of Physical Education and Sport, 14 (4): 493-496.

Behncke, L. (2004). Mental skills training for sports: A brief review. The online Journal of Sport Psychology, 6 (1):1-19.

Ben Abdelkrim, N., El Fazaa, S., El Ati, J. (2007). Time-motion analysis and physiological data of elite under-19-year-old basketball players during competition, British Journal of Sports Medicine, 41(2):69-75. https://doi.org/10.1136/bjsm.2006.032318

Bompa, T.O., \& Haff, G.G. (2009). Periodization. Theory and Methodology of Training. Il: Human Kinetics.

Bourbousson, J., Seve, C., McGarry, T. (2010). Space-time coordination dynamics in basketball: Part 2. The interaction between the two teams. Journal of Sports Sciences, 28, 349:358. https://doi.org/10.1080/02640410903503640 
Burgess, D.J., \& Naughton, G.A. (2010). Talent development in adolescent team sports: A review. International journal of sports physiology and performance, 5(1), 103-116. https://doi.org/10.1123/ijspp.5.1.103

Ceruso, R., Esposito, G., D'Elia, F. (2019). Analysis and evaluation of the qualitative aspects of the young players. Journal of Physical Education and Sport, 19 (5 S):1814-1819.

Crisafulli, A., Melis, F., Tocco, F., Laconi, P., Lai, C., Concu, A. (2002). External mechanical work versus oxidative energy consumption ratio during a basketball field test. Journal of Sports Medicine and Physical Fitness, 42: 409-417.

D'Elia, F., Sgrò, F., \& D'Isanto, T. (2020). The educational value of the rules in volleyball. Journal of Human Sport and Exercise, 15(3proc), S628-S633. https://doi.org/10.14198/ihse.2020.15.Proc3.15

D'Isanto, T., D'Elia, F., Raiola, G., Altavilla, G. (2019). Assessment of sport performance: Theoretical aspects and practical indications. Sport Mont, 17 (1): 83-89. https://doi.org/10.26773/smj.190214

Esposito, G., Ceruso, R., D'Elia, F., \& D'Isanto, T. (2020a). Performance anxiety: How to play reliable and rational tennis by reducing mental pressure. Journal of Human Sport and Exercise, 15(2proc), S213-S221. https://doi.org/10.14198/jhse.2020.15.Proc2.12

Esposito, G., D'Elia, F., \& Raiola, G. (2020b). A Method to Promote the Development of Intelligence and Game Skills in Youth Football. Teoriâ Ta Metodika Fìičnogo Vihovannâ, 20(3), 142-148. https://doi.org/10.17309/tmfv.2020.3.03

Falcone, G., Scurati, R., D'Elia, F., \& D'Isanto, T. (2019). Basketball and ankle injuries. Journal of Human Sport and Exercise, 14(4proc), S1142-S1148. https://doi.org/10.14198/jhse.2019.14.Proc4.79

Federici, D., Troiano, G., \& Valentini, M. (2014). Sport as a life project. Rivista: Formazione \& Insegnamento, XII, (4):255-271. Lecce, Pensa MultiMedia.

Ferrara, F., Izzo, R., Ceciliani, A., Di Tore, A.P. (2019). Pilot study on the testing of Power Glove applied to volleyball. Journal of Human Sport and Exercise, 14(proc.2): S233-S238. https://doi.org/10.14198//hse.2019.14.Proc2.11

Gaetano, R., Gomez, F.P., Gaetano, A. (2015). Anxiety In The Youth Physical And Sport Activity, $\begin{array}{lllll}\text { Mediterranean Journal of Social Sciences, } 6 & \text { (3): 227-230. }\end{array}$ https://doi.org/10.5901/mjss.2015.v6n3s2p227

Gréhaigne, J., Godbout, P., \& Bouthier, D. (1999). The Foundations of Tactics and Strategy in Team Sports, Journal of Teaching in Physical Education, 18(2), 159-174. https://doi.org/10.1123/itpe.18.2.159

Haga, M., Tortella, P., Asonitou, K., Charitou, S., Koutsouki, D., Fumagalli, G., Sigmundsson, H. (2018). Cross-cultural aspects: Exploring motor competence among 7 to 8 year old children from Greece, Italy and Norway. Sage open, 8(2), 2158244018768381. https://doi.org/10.1177/2158244018768381

Helsen, W. F., Starkes, J. L., \& Hodges, N. J. (1998). Team sports and the theory of deliberate practice. Journal of Sport and Exercise psychology, 20(1): 12-34. https://doi.org/10.1123/jsep.20.1.12

Kamandulis, S., Venckunas, T., Masiulis, N., Matulaitis, K., Balci unas, M., Peters, D. (2013). Relationship between general and specific coordination in 8- to 17-year-old male basketball players. Percept. Mot. Skills 117, 821-836. https://doi.org/10.2466/25.30.PMS.117x28z7

Izzo, R., Sopranzetti, S., Altavilla, G. (2015). Biomechanical analysis of fundamentals in basketball the rebound - Ovidius University Annals, Series Physical Education and Sport / Science, Movement and Health, 15 (2): 122-126.

Narazaki, K., Berg, K., Stergiou, N., Chen, B. (2009). Physiological demands of competitive basketball, Scandinavian Journal of Medicine \& amp; Science in Sports, 19: 425-432. https://doi.org/10.1111/j.1600-0838.2008.00789.x

Raiola, G., Esposito, G., \& Sgrò, F. (2020). The formative value of soccer rules. Journal of Human Sport and Exercise, 15(3proc), S656-S663. https://doi.org/10.14198/ihse.2020.15.Proc3.18 
Raiola, G., \& D'Isanto, T. (2017). Assessment of periodization training in soccer. Journal of Human Sport and Exercise, 11(1proc), S267-S278. https://doi.org/10.14198/ihse.2016.11.Proc1.19

Raiola, G., Altavilla, G., Tafuri, D, Lipoma, M, (2016). Analysis of learning of shot in basketball, Journal of physical education, 5 (1): 3-7.

Raiola, G. (2015). Basketball feint and non-verbal communication: empirical framework. Journal of Human Sport and Exercise, 10(1proc), S360-S368. https://doi.org/10.14198/jhse.2015.10.Proc1.26

Schot, P., Dart, J., Schuh, M. (1995). Biomechanical analysis of two changes of direction maneuvers while running. Journal of Orthopaedic \& Sports Physical Therapy, 22(6):254-258. https://doi.org/10.2519/jospt.1995.22.6.254

Sgrò, F., Quinto, A., Platania, F., Lipoma, M. (2019). Assessing the impact of a physical education project based on games approach on the actual motor competence of primary school children. Journal of Physical Education and Sport, 19:781-786.

Sgrò, F., Quinto, A., Messana, L., Pignato, S., Lipoma, M. (2017). Assessment of gross motor development level in italian primary school children. Journal of Physical Education and Sport, 17(3): 1954-1959.

Tortella, P., Haga, M., Ingebrigtsen, J.E., Sigmundsson, H., Fumagalli, G.F. (2019). Comparing free play and partly structured play in 4-5 years old children in an outdoor playground. Frontiers in public health, 7, 197. https://doi.org/10.3389/fpubh.2019.00197

Valentini, M., Riccardi, F., Raiola, G., Federici, A. (2018). Educational research: motor area and relational area during children's personality development, Journal of Physical Education and Sport, 18(Suppl. 5):2157-2174. 